was observed. In addition, a significant increase in muscle strength and a reduction in body fat could be demonstrated.

Conclusion Due to the initial significantly reduced cardiorespiratory fitness of the patients, but with promising first data showing a benefit of the patients after the training program, a follow-up study with a larger SLE patient collective over a period of 2 years is planned. In addition, a murine comparative study will be initiated in the spontaneous lupus mouse model of the MRL-Fas lpr mice. On the one hand, the influence of physical exercise on disease activity and progression of SLE should be analysed. Furthermore, we want to investigate the effects of physical activity on the musculature (inflammation, necrosis and fibrosis) and cardiovascular damage.

\section{P126 TOLERABILITY, EFFICACY AND ADHERENCE: WHAT DO LUPUS PATIENTS THINK ABOUT TREATMENT?}

Elvira Chocano Navarro, George Robinson, Lucia Martin Gutierrez, Thomas McDonnell, Kirsty Waddington, Elizabeth Jury, Coziana Ciurtin, Chris Wincup. Dept. of Rheumatology, University College London, London, UK

\subsection{6/lupus-2020-eurolupus. 170}

Background The treatment of systemic lupus erythematosus (SLE) can be challenging due to the complex nature of symptoms, yet despite recent advances in treatment, patients' opinion and medication beliefs are poorly understood. Furthermore, patient understanding of treatment plays a major role in medication adherence. In this study we aimed to understand patient experiences relating to treatment.

Methods Thirteen patients attended a patient engagement event. They were asked to answer 12 structured treatmentbased questions designed to assess medication beliefs. Round table discussions were held where patients shared their experiences to allow for both qualitative and quantitative data collection.

Results The majority of patients (74.5\%) believed that they had a good understanding of their current treatment with many accessing medication-related information though consultation with their rheumatologist or specialist nurse (93.3\%),

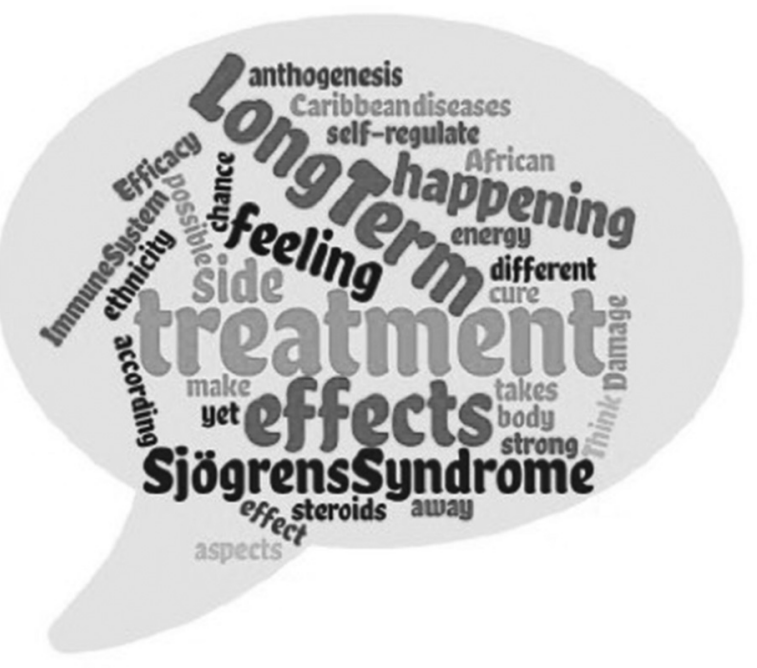

Abstract P126 Figure 1 'Word Cloud' Analysis of patient concerns prior to starting treatment

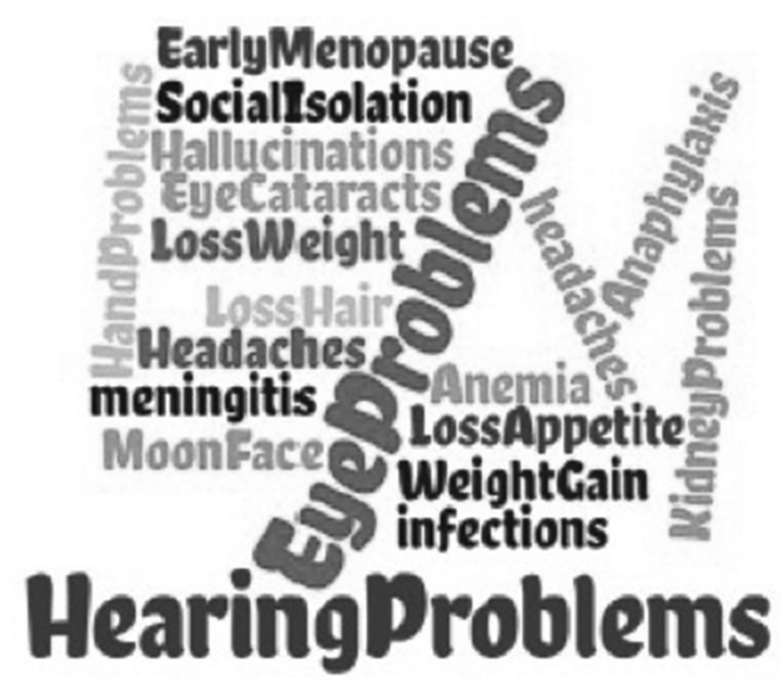

Abstract P126 Figure 2 'Word Cloud' Analysis of perceived side effects experienced by patients

via patient information sheets (33\%) and by using online resources $(46.6 \%)$.

Many patients (76.9\%) reported that they had concerns before starting a new treatment, in particular in relation to potential side effects and ultimate treatment duration. A substantial number $(75 \%)$ of patients reported a previous adverse reaction or side effect to treatment. Just over half of participants $(54.6 \%)$ were previously advised by their doctor to stop taking a medication because it was not effective. Interestingly, 40\% said they had stopped taking their medication on their own accord, usually due to side effects, with $54.5 \%$ reported stopping treatment due to feeling it to be ineffective. Figure 1 shows 'World Cloud' qualitative analysis of patient responses regarding concerns prior to starting treatment. Figure 2 shows perceived side effects reported by participants. Over 90\% of respondents thought more research should be performed in investigating potential side effects and to identify those who will respond well prior to starting a treatment.

Conclusions In summary this work shows that patients are concerned about adverse events associated with treatment and supports new research to identify ways to mitigate those effects.

\section{P127 LONG-TERM EFFECTS OF COMBINED B-CELL IMMUNOMODULATION WITH RITUXIMAB AND BELIMUMAB IN SEVERE, REFRACTORY SLE: TWO YEAR RESULTS RITUXIMAB AND BELIMUMAB COMBINATION FOR SEVERE SLE}

${ }^{1}$ Tineke Kraaij, ${ }^{1}$ Eline J Arends, 'Laura S van Dam, 'Sylvia WA Kamerling, ${ }^{2}$ Paul LA van Daele, 'Obbo W Bredewold, 'Argho Ray, ${ }^{3}$ Jaap A Bakker, ${ }^{4}$ Hans U Scherer, ${ }^{4}$ Tom JW Huizinga, ${ }^{1}$ Ton J Rabelink, ${ }^{1}$ Cees van Kooten, ${ }^{1} Y$ K Onno Teng. 'Dept of Nephrology, LUMC, Leiden; ${ }^{2}$ Dept of Clinical Immunology, Erasmus MC, Rotterdam; ${ }^{3}$ Dept of Clinical Chemistry and Laboratory Medicine, LUMC, Leiden; ${ }^{4}$ Dept of Rheumatology, LUMC, Leiden, The Netherlands

\subsection{6/lupus-2020-eurolupus. 171}

Background Anti-CD20 B-cell depletion has not shown superior efficacy to standard immunosuppression in patients with systemic lupus erythematosus (SLE). Besides trial design, 
potential explanations are incomplete B-cell depletion in relation to substantial surges in B-cell activating factor (BAFF). To improve B-cell targeting strategies, we conducted the first study in SLE patients aimed at investigating immunological effects and feasibility of combining rituximab (anti-CD20) and belimumab(anti-BAFF).

Methods Reported is the long-term follow-up of a phase 2 proof-of-concept study in 15 patients with SLE including 12 (80\%) with lupus nephritis (LN).

Results In 10/15(67\%) patients a clinical response was observed by achievement of lupus low disease activity state (LLDAS) of which $8(53 \%)$ continued treatment (belimumab $+\leq 7,5 \mathrm{mg}$ prednisolone) during the complete 2 years of follow-up. Five patients (33\%) were referred to as 'non-responders' due to persistent $\mathrm{LN}$, major flare or repeated minor flare. Out of $12 \mathrm{LN}$ patients $9(75 \%)$ showed a renal response including $8(67 \%)$ complete renal responders. All anti-dsDNA ${ }^{+-}$ patients converted to negative and both anti-C1q and extractable nuclear antigen autoantibodies (ENAs) showed significant reductions. $\mathrm{CD} 19^{+} \mathrm{B}$-cells showed a median decrease from baseline of $97 \%$ at 24 weeks, with a persistent reduction of $84 \%$ up to 104 weeks. When comparing responders to nonresponders, CD $20^{+} \mathrm{B}$-cells were depleted significantly less in non-responders and double negative (DN) B-cells repopulated significantly earlier.

Conclusion Combined B-cell targeted therapy with rituximab (RTX) and belimumab (BLM) prevented full B-cell repopulation including DN B-cells, with concomitant specific reduction of SLE-relevant autoantibodies. The observed clinical and immunological benefits in a therapy-refractory SLE population prompt further studies on RTX+BLM.

Acknowledgements This work is funded by the Dutch Kidney Foundation (KJPB12.028), Clinical Fellowship from the Netherlands Organization for Scientific Research (90713460) and GlaxoSmithKline (GSK) provided belimumab and an unrestricted grant for the clinical study.

\section{P128 EFFICACY OF INTRAVENOUS BELIMUMAB IN CHILDREN WITH SYSTEMIC LUPUS ERYTHEMATOSUS WITH MARKERS OF HIGH DISEASE ACTIVITY: ACROSS-TRIAL COMPARISON WITH ADULT BELIMUMAB STUDIES}

${ }^{1}$ Damon L Bass, ${ }^{2}$ Mohamed Okily, ${ }^{1}$ Anne Hammer, ${ }^{3}$ Beulah Ji, ${ }^{1}$ David Roth, ${ }^{4}$ Holly Quasny. 'GlaxoSmithKline, Collegeville, USA; ${ }^{2}$ GlaxoSmithKline, Uxbridge; ${ }^{3}$ GlaxoSmithKline, Stevenage, UK; ${ }^{4}$ GlaxoSmithKline, Research Triangle Park, USA

\subsection{6/lupus-2020-eurolupus. 172}

Background Belimumab is approved as add-on therapy for patients $\geq 5$ years with active, autoantibody-positive systemic lupus erythematosus (SLE). ${ }^{1}$ The PLUTO trial (NCT01649765) demonstrated safety and efficacy of belimumab in children with SLE $^{2}$ as generally consistent with adult studies. The current analysis assessed the efficacy of belimumab $10 \mathrm{mg} / \mathrm{kg}$ given intravenously (IV) to patient subgroups with baseline markers of high disease activity in PLUTO versus pooled BLISS-52 (NCT00424476) and BLISS-76 (NCT00410384) SLE trials.

Methods Patients 5-17 years (PLUTO) and $\geq 18$ years (BLISS-52 and BLISS-76) with active SLE were randomised to IV belimumab $10 \mathrm{mg} / \mathrm{kg}$ or placebo, plus standard of care (SoC) (PLUTO); ${ }^{2}$ and IV belimumab $10 \mathrm{mg} / \mathrm{kg}$, or
Abstract P128 Table 1 SRI4 response at Week 52 by subgroup for PLUTO and the pooled BLISS-52 and BLISS-76 studies (ITT population)

\begin{tabular}{llll}
\hline $\begin{array}{l}\text { PLUTO (paediatric; 5-17 } \\
\text { years) } \\
(\mathrm{N}=93)\end{array}$ & $\begin{array}{l}\text { BLISS-52 and BLISS-76 (adult; } \\
\geq 18 \text { years) } \\
(\mathrm{N}=1684)\end{array}$ \\
\hline $\begin{array}{llll}\text { Placebo } \\
(\mathrm{n}=40)\end{array}$ & $\begin{array}{l}\text { Bg IV } \\
(\mathrm{n}=53)\end{array}$ & $\begin{array}{l}\text { Placebo } \\
(\mathrm{n}=562)\end{array}$ & $\begin{array}{l}\text { Belimumab } 1 \mathrm{k}^{\dagger} \\
(\mathrm{n}=563)\end{array}$ \\
\hline
\end{tabular}

ITT population

$\mathrm{N}$

$39 \quad 53$

Response, $\mathrm{n}(\%)$

(43.6)

28 (52.8)

$562 \quad 563$

Difference, BEL vs

9.24

218

285 (50.6)

PBO, \%

$1.49(0.64,3.46)$

(38.8)

11.83

OR $(95 \% \mathrm{Cl})$

Baseline SELENA-SLEDAI score $\geq 10$

N

Response, n (\%)

$25 \quad 31$

$$
\begin{aligned}
& 12 \\
& (48.0)
\end{aligned}
$$

18 (58.1)

Difference, BEL vs

(48.0)

10.06

$\mathrm{PBO} \%$

$1.50(0.52,4.33)$

OR $(95 \% \mathrm{Cl})$

Baseline SELENA-SLEDAI score $\leq 9$

N

Response, $\mathrm{n}(\%)$

$14 \quad 22$

Difference, BEL vs

5 (35.7) $10(45.5)$

$\mathrm{PBO} \%$

9.74

$1.50(0.38,5.95)$

OR $(95 \% \mathrm{Cl})$

Baseline SELENA-SLEDAI score $\geq 13$

$\mathrm{N}$

Response, $\mathrm{n}(\%)$

$6 \quad 10$

Difference, BEL vs

$2(33.3) \quad 6(60.0)$

$\mathrm{PBO} \%$

26.67

OR $(95 \% \mathrm{Cl})$

Baseline SELENA-SLEDAI score $\leq 12$

N

Response, $\mathrm{n}(\%)$

$\begin{array}{ll}33 & 43 \\ 15 & 22(51.2)\end{array}$

Difference, BEL vs

(45.5)

$\mathrm{PBO} \%$

5.71

$1.26(0.51,3.12)$

OR $(95 \% \mathrm{Cl})$

Baseline anti-dsDNA $\geq 30 \mathrm{IU} / \mathrm{mL}^{*}$

N

Response, n (\%)

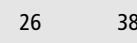

11
$(42.3)$

18 (47.4)

Difference, BEL vs

(4)

5.06

$\mathrm{PBO} \%$

$1.23(0.45,3.35)$

OR $(95 \% \mathrm{Cl})$

Baseline anti-dsDNA $<30 \mathrm{IU} / \mathrm{mL}^{*}$

N

Response, $\mathrm{n}$ (\%)

$13 \quad 15$

Difference, BEL vs

$6(46.2) \quad 10(66.7)$

$\mathrm{PBO} \%$

20.51

OR $(95 \% \mathrm{Cl})$

Baseline low C3 ${ }^{*}$

N

Response, $n$ (\%)

Difference, BEL vs

PBO,\%

$2.33(0.51,10.78)$

$\begin{array}{ll}299 & 296 \\ 132 & 187(63.2) \\ (44.1) & \\ & 19.03\end{array}$

$2.22(1.59,3.10)$

$263 \quad 267$

86 (32.7) 98 (36.7)

4.00

$1.16(0.81,1.67)$

$87 \quad 89$

$39(44.8) \quad 50(56.2)$

11.35

$1.63(0.89,3.00)$

OR $(95 \% \mathrm{Cl})$ 